\section{TELESCOPIC WORK.}

Telescopic Work for Starlight Evenings. By W. F. Denning, F.R.A.S. (London: Taylor and Francis, I89i.)

$\Delta \mathrm{S}$ might be expected from such an experienced and A enthusiastic observer as Mr. Denning, this book is thoroughly practical. $\mathrm{He}$ is not contented with describing the beauties of the skies, but gives invaluable information as to how to see them best. The opening chapters give a very complete history of the invention and development of the powers of the telescope and its accessories. These are followed by chapters on the sun, moon, planets, stars, nebulæ, and clusters ; the sun being introduced for the sake of completeness, although not comprehended in the title. The question of the relative advantages of large and small telescopes is discussed at considerable length, and one almost gets the impression that large telescopes, except under very favourable conditions, are not desirable possessions. It is very gratifying to note the encouragement given to observers of limited means. To them the book will be of the greatest assistance, both in the selection and use of their instruments.

The author's style is such as to make the book very entertaining as well as instructive. Some of his remarks are well worth quoting, as, for example, his opinion of controversy in scientific matters.

"Competition and rivalry in good spirit increase enthusiasm, but there is little occasion for the bitterness and spleen sometimes exhibited in scientific journals. There are some men whose reputations do not rest upon good or original work performed by themselves, but rather upon the alacrity with which they discover grievances, and upon the care they will bestow in exposing trifling errors in the writings of their not-infallible contemporaries. Such critics would earn a more honourable title to regard were they to devote their time to some better method of serving the cause of science" (p. 56).

Mr. Denning is very emphatic in his opinion that an observer's time is too valuable to be spent in acting the showman to his friends and acquaintances. If all observers were so disposed, there might be reasonable hope for the establishment in this country of some such institution as the Gesellschaft Urania in Berlin, for the special gratification of persons desiring passing glimpses of celestial wonders.

It is scarcely necessary to say that the chapter on meteoric observations is as good as can be. More observers are undoubtedly needed in this branch of astronomy, and volunteers will find very full instructions in the pages of this book. In addition to the notes on variable stars given by the author, we would suggest the tracing of the light-curves of a small number of stars by each observer. Anyone at present attempting to determine the laws governing variability will find such information lamentably deficient.

The book is full of important practical details, and an appendix gives the chief new facts up to March 5, I89I.

The book does not attempt to deal with spectroscopic matters, but occasional references are made, and it is here, if anywhere, that fault may be found. Thus, referring to the nebula of Orion, it is stated (p. 334) that

"the spectroscopic researches of Huggins have shown this nebula to be composed of incandescent gases, so that the stars telescopically observed in it are probably in the foreground and entirely disconnected from the nebulous mass."

In I888, however, it was shown by the spectrosrope that the stars of the trapezium, at all events, are simply condensations of the matter composing the nebula.

Everyone who uses a telescope, or who intends to use one, of whatever dimensions, should read Mr. Denning's book.

\section{OUR BOOK SHELF.}

Abbildungen zur Deutschen Flora H. Karsten's, nebst den ausländischen medicinischen Pflanzen und Ergänzungen fïr das Studium der Morphologie und Systemkunde. With Woodcuts of 709 Species. (Berlin : Friedländer und Sohn, I 891.)

THIS is a wonderfully cheap book, for the price of it is only three marks, and it contains figures with dissections of upwards of 700 plants, illustrating all the natural orders both of Cryptogamic and Phanerogamic plants which make up the European flora or are used medicinally. The text is confined to the preliminary table of the orders and families, an explanation of the cietails, and a final index.

The Thallophytæ are divided into I7 families, classed under 3 orders, Lichenes being maintained as on a par with Algæ and Fungi. In Cormophytæ there are I6 families under 6 orders, the orders of Sporiferæ being Filices, Selagines, Rhizocarpeæ, and Calamariæ. In Northocarpæ (Gymnosperms) there are 7 families under 5 orders, Balanophoraceæ and Lorantheæ being placed here. Under Teleocarpæ (Angiosperms) there are I 59 families classed under 48 orders, Dicotyledons being divided into Monochlamydeæ and Dichlamyder, and the latter into Petalantheæ (Polypetalæ) and Corollanthæ (Gamopetalæ). The "families" correspond substantially to Bentham and Hooker's orders. To have such a good and cheap book in English (the text in the original, of course, is German) would be a great boon to students.

Eiementary Text-book of Botany for the Use of Schools. By Edith Aitkin. 248 pp. (London : Longmans, Green, and Co., I 89I.)

THIS volume has been written to serve as an adjunct to the teaching of Botany in girls' schools, and is the outcome of the author's own experience as a teacher. Miss Aitkin arranges the subject-matter in three parts. In the first are given the general characters of a number of selected types of Flowering plants treated in a manner suitable for young girls beginning the study. In the second part the details of Cryptogamic plants are given, commencing with Protococcus and Yeast, and so on, up to the Fern. In the third part we return to Flowering plants again from a more comprehensive point of view. This last section concludes with a number of chapters on the leading physiological processes of plants. We think the book will be found of service by those for whom it is intended, especially from the fact that Part I. is written, generally speaking, on the lines of the Lower Schedule laid down by the Oxford and Cambridge Schools Examination Board. The only criticism we have to make on this section is that perhaps the style is a little wanting in vitality and interest. Part II. is treated along sufficiently familiar lines, but in Part III., by the introduction of physiological work, with careful instructions as to simple experiments which can easily be performed to illustrate class teaching, we think that the author will have opened up fresh fields of interest in botanical study. The volume is profusely illustrated, many of the figures being new. 